\title{
Does the cervical canal passage axis have an effect on pain sensation in IUD application?: a randomized controlled trial
}

\author{
RİA uygulamasında servikal kanalı geçiş ekseninin ăgrı hissine etkisi var \\ mıdır?: randomize kontrollü bir çalışma
}

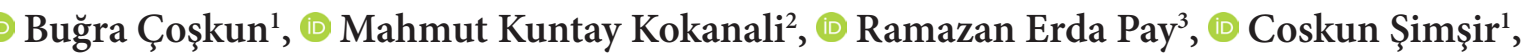 \\ (1) Mehmet Ferdi Kinci ${ }^{4}$, (1) Bora Çoşkun ${ }^{1}$, (1) Tolga Ecemişs ${ }^{5}$, (1) Kazım Emre Karaşahin ${ }^{6}$ \\ ${ }^{1}$ Yüksek İhtisas University, Department of Obstetrics and Gynecology, Ankara, Turkey \\ ${ }^{2}$ University of Health Sciences, Ankara Bilkent City Hospital, Department of Obstetrics and Gynecology, Ankara, Turkey \\ ${ }^{3}$ Bingöl Maternity and Child Diseases Hospital, Department of Obstetrics and Gynecology, Bingöl, Turkey \\ ${ }^{4}$ Muğla Sitkı Koçman University, Department of Obstetrics and Gynecology, Ankara, Turkey \\ ${ }^{5}$ Private Office of Obstetrics and Gynecology, Ankara, Turkey \\ ${ }^{6}$ University of Health Sciences, Gulhane Medical Faculty, Department of Obstetrics and Gynecology, Ankara, Turkey
}

Cite this article as / Bu makaleye atıf için: Çoşkun B, Kokanalı MK, Pay RE, et al. Does the cervical canal passage axis have an effect on pain sensation in IUD application?: a randomized controlled trial. J Health Sci Med 2020; 3(3): 330-335.

\begin{abstract}
Aim: To investigate the effect of the axis of the intrauterine device wings in the cannula on the pain felt while passing the cervical canal. Material and Method: Ninety-one patients who underwent intrauterine device application in the family planning policlinic were enrolled in the study. The patients were randomly divided into two groups according to the intrauterine device application sequence number. Odd numbers were included in the 'Transverse application' (Group I), while even numbers were included in the 'Vertical application' (Group II) group. After the procedure, patients were informed about the visual analog scale by another doctor who did not perform the procedure. Patients rated pain intensity during the procedure from 0 (zero, painless) to 10 (ten, highest pain) on a visual analog scale.

Results: No statistically significant difference was found between the groups in terms of age, gravida, parity, body mass index, cervical length, previous cesarean history, presence of retroverted uterus. There was no statically significant difference according to visual analog scale scores between the groups, but the mean visual analog scale score was lower in Group II. Also, the presence of severe pain (visual analog scale score $>8$ ) was statistically significantly higher in Group I. Transverse application procedure (OR: 1.21, 95\% CI: 0.21-6.70, p=0.042) was found to be a significant independent factor for the presence of severe pain in multiple regression analysis.

Conclusion: In the intrauterine device application procedure, passing the cervical canal while the wings in cannula are in the vertical axis has been associated with less pain felt.
\end{abstract}

Keywords: Intrauterine device, pain, visual analog scale

\section{ÖZ}

Amaç: Rahim içi araç uygulamasında servikal kanal geçerilirken kanül içerisindeki kanatların ekseninin hissedilen ağrıya etkisini araştırmak

Gereç ve Yöntem: Aile planlaması polikliniğinde rahim içi araç uygulaması yapılan 91 hasta çalışmaya dahil edildi. Hastalar rahim içi araç uygulama sıra numarasına göre rastgele iki gruba ayrıld. Tek sayılar 'Yatay uygulama' (Grup I), çift sayılar ise 'Dikey uygulama' (Grup II) grubuna dahil edildi. İşlem sonrası hastalar, başka bir doktor tarafından vizüel analog skala hakkında bilgilendirildi ve işlem sırasında hissettikleri ağrı yoğunluğunu vizüel analog skalaya göre 0 (sıfır, ağrısız) ila 10 (on, en yüksek ağrı) arasında derecelendirdi.

Bulgular: Gruplar arasında yaş, gravida, parite, vücut kitle indeksi, servikal uzunluk, sezaryen öyküsü, retrovert uterus varlığı açısından istatistiksel olarak anlamlı bir fark yoktu. Gruplar arasında vizüel analog skala skorlarına göre istatistiksel olarak anlamlı fark yoktu, ancak Grup II'de ortalama vizüel analog skala skoru daha düşüktü. Ayrıca Grup I’deki şiddetli ağrı varlığı (vizüel analog skala skoru>8) istatistiksel anlamlı daha yüksekti. Enine uygulama prosedürü (OR:1,21, \%95 CI:0,21-6,70, p=0,042) çoklu regresyon analizinde şiddetli ağrı varlığı için anlamlı bir bağımsız faktör olarak bulunmuştur.

Sonuç: Rahim içi araç uygulama prosedüründe, kanüldeki kanatlar dikey eksendeyken servikal kanalı geçmek daha az ağrı hissi ile ilişkilendirilmiştir.

Anahtar Kelimeler: Rahim içi cihaz, ağrı, vizüel analog skala 


\section{INTRODUCTION}

Family planning is defined as the practice of controlling the number of children one has and the intervals between their births. (1). Contraception is all methods of evading from pregnancy. In developing countries, maternal deaths have decreased by $40 \%$ in the past 20 years due to the prevention of unintended pregnancies (2). The methods used for contraception vary across years, countries and socio-economic status (3).

Intrauterine device (IUD) is an effective, inexpensive, long-lasting, and a reversible contraception method. The cumulative pregnancy rate is $1 / 100$ for the first year of use (4). The mechanism of action is to prevent sperm and egg from combining by decreasing sperm mobility and preventing implantation by creating a foreign body reaction in the endometrial cavity (3). The IUD can be inserted at any time if it is sure that it is not pregnancy. The IUD can be implanted during a normal postpartum period or after cesarean section (5).

Methods that can reduce the pain that may occur in the patient during any gynecological procedure (Hysterosalpingography, Dilatation and curettage, hysteroscopy, IUD placement, etc.) performed in the outpatient clinic conditions attract the attention of gynecologists $(6,7)$.

Usage of misoprostol before the procedure, use of oral analgesics such as naproxen, ibuprofen, and implementation of topical analgesics to the cervix such as lidocaine have been tried to increase patient comfort during IUD insertion. Still, there is no consensus on their effectiveness and necessity (8-10).

In this study; We aimed to investigate whether the application of the wings on the transverse or vertical axis while the cervical canal was being passed during the IUD application had any effect on the pain experienced by the patients.

\section{MATERIAL AND METHOD}

The study was designed as a single-blind randomized prospective trial. This study was approved by the university /local human research ethics committee and all procedures performed in studies involving human participants were in accordance with the ethical standards of the institutional and/or national research committee and with the 1964 Helsinki Declaration and its later amendments or comparable ethical standards. The study was carried out with the permission of University of Health Sciences Ankara Gulhane Medical Faculty Ethics Committee (Permission granted: 25/09/2018, Decision No: $18 / 229)$.
The patients who underwent IUD application in the family planning policlinic between August 2018 and August 2019 and that meet the determined criteria were enrolled in the study. Patients deemed to be eligible were randomly divided into two groups. Randomization was performed according to the application sequence number. Odd numbers were included in the 'Transverse application' group, while even numbers were in the 'Vertical application' group.

\section{Inclusion criteria}

1) Between 19-49 years of age and not having a systemic disease, 2) Having at least one vaginal delivery story before, 3) Not being pregnant or having at least one month pasted pregnancy, 4) No known allergic reaction sensitivity for IUD or copper, 5) No history of chronic pelvic pain or dysmenorrhea, 6) No anatomical anomaly of the uterus or pathologies such as myoma uteri associated with the cavity, 7) No evidence of active vaginal or pelvic infection.

\section{Exclusion criteria}

1) Nulliparity, 2) The need for a cervical dilator during the insertion of IUD, 3) The presence of a systemic disease that could change the sensation of pain, 4) The patient had cognitive functions that could not correlate with the VAS score.

\section{Intrauterine device (IUD) application procedure}

The intrauterine device (Althea TM -TCu-380A, Daman India) was applied. Transvaginal ultrasound before application to confirm the shape and size of the uterus and exclude other pelvic pathologies to each patient and digital pelvic examination was performed. Written informed consent was obtained from patients eligible to participate in the study.

After the patient was prepared for a lithotomy position, the speculum prepared with standard medical gel was placed. After the cervix was visualized, the area was cleaned with povidone-iodine. Then, the cervix was gripped with a tenaculum at 11 oclock, and the uterus was applied traction towards the straight axis. IUD wings were taken into the cannula and made ready for application. (Figure 1)

The intrauterine device was passed through the cervical canal in a transverse (Figure 2) or vertical axis (Figure 3) in accordance with randomization. In patients with the vertical passage, the cannula was rotated at the fundus level and the wings were brought to the transverse line and the IUD was left in the cavity. All IUD insertions were performed by the same doctor. 


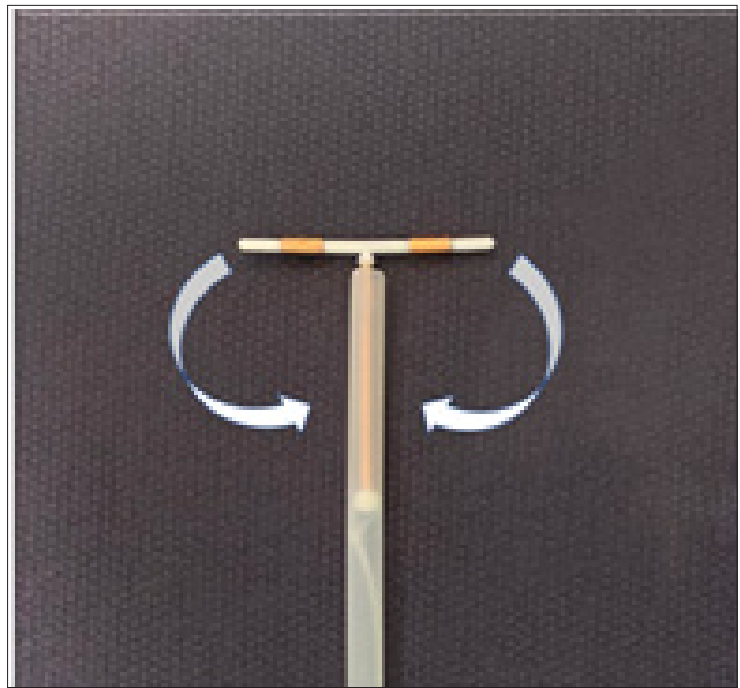

Figure 1. Intra uterine device and preparation before application Before the application, the IUD wings are placed in the application cannula in the direction indicated by the arrows.

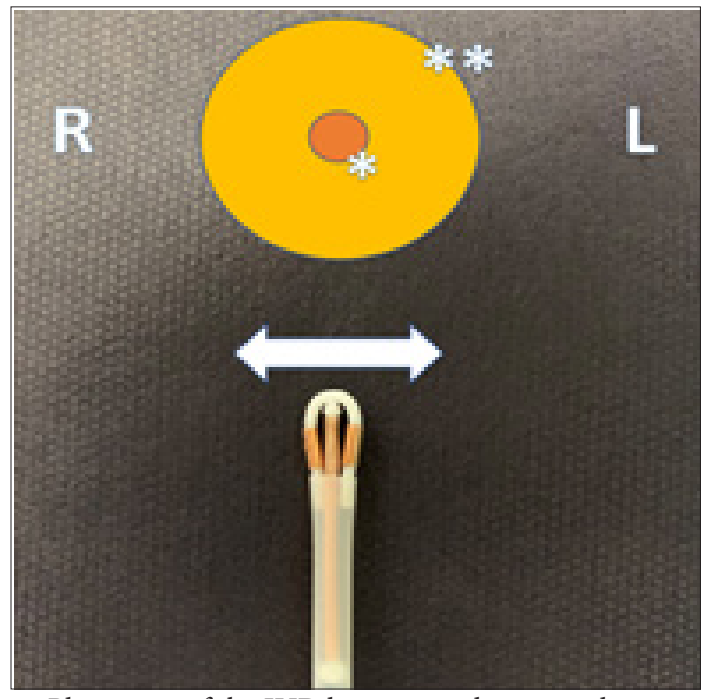

Figure 2. Placement of the IUD by passing the cervical ostium while the wings in the cannula are on the transverse axis

${ }^{*}$ Demostration of the cervical ostium, ${ }^{*}$ Demostration of the cerviks, R:Right, L:Left

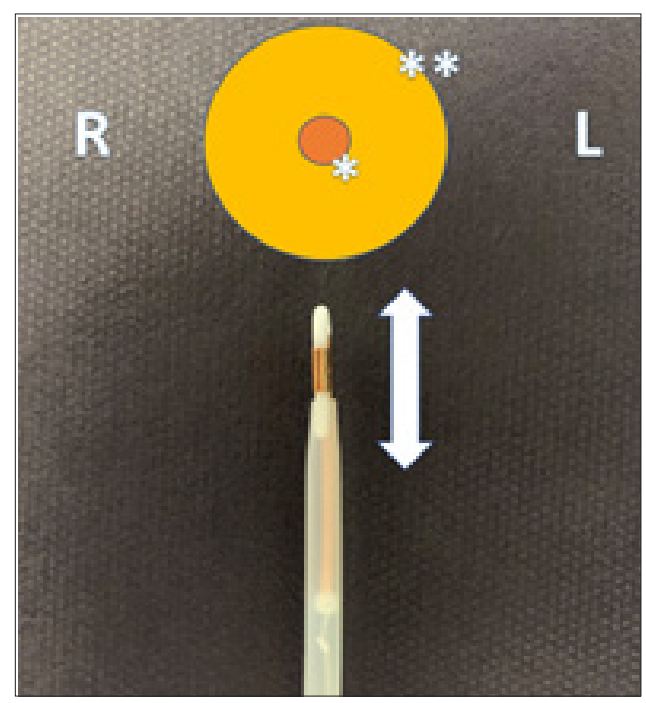

Figure 3. Placement of the IUD by passing the cervical ostium while the wings in the cannula are on the vertical axis

${ }^{*}$ Demostration of the cervical ostium, ${ }^{*}$ Demostration of the cerviks, R:Right, L:Left
Immediately after the procedure, patients were informed about VAS by another doctor. Patients rated pain intensity during the procedure from 0 (zero, painless) to 10 (ten, highest pain) on VAS. The doctor, who gave patient's information about VAS and recorded the pain assessment results, did not know which group the patients were evaluated to.

\section{Statistics}

"Statistical analysis was performed using the Statistical Program for Social Sciences (SPSS, Version 21.0; Chicago, IL, USA). The normal distribution of the variables was analysed by the Kolmogorov-Smirnov test. Continuous variables with normal distribution were presented as mean \pm standard deviation. Quantitative variables were given as a number (percentage). Statistical comparison was carried out by Chi-square $\left(\chi^{2}\right)$ and Independent sample t-tests where appropriate. Multiple logistic regression model was performed to analyse the factors that can cause severe pain. $\mathrm{P}<0.05$ was considered statistically significant."

\section{RESULTS}

As a result of the exclusion criteria, 22 patients were excluded from the study, and 91 patients who met the inclusion criteria were enrolled in the study. Forty-six patients were applied "Transverse axis application" while 45 patients were applied on vertical axis application

The demographic findings of both groups are shown in Table 1. In our study, no statistically significant difference was found between the groups in terms of age, gravida, parity, body mass index (BMI), cervical length, previous caesarean history, presence of uterus in a retrovert position ( $p>0.05$ for all values) (Table 1 ).

Table 1. The comparison of demographic variables of transverse and vertical application groups

\begin{tabular}{|c|c|c|c|}
\hline & $\begin{array}{c}\text { Transverse } \\
(n=46)\end{array}$ & $\begin{array}{l}\text { Vertical } \\
(n=45)\end{array}$ & $\mathbf{P}$ \\
\hline Age $(\text { year) })^{*}$ & $36.57 \pm 5.92$ & $36.78 \pm 5.27$ & 0.857 \\
\hline Gravida * & $3.68 \pm 1.99$ & $3.60 \pm 1.90$ & 0.855 \\
\hline Parity * & $2.83 \pm 1.40$ & $2.67 \pm 1.35$ & 0.582 \\
\hline BMI $(\mathrm{kg} / \mathrm{m} 2)^{*}$ & $26.82 \pm 5.40$ & $26.39 \pm 5.44$ & 0.702 \\
\hline Cervical length $(\mathrm{mm})^{*}$ & $39.43 \pm 5.45$ & $37.40 \pm 6.06$ & 0.095 \\
\hline $\begin{array}{l}\text { Presence of previous } \\
\mathrm{C} / \mathrm{S}^{* *}\end{array}$ & $14(30.4 \%)$ & $15(33.3 \%)$ & 0.767 \\
\hline Retrovert uterus ${ }^{\star *}$ & $11(23.9 \%)$ & $14(31.1 \%)$ & 0.442 \\
\hline $\begin{array}{l}\text { The history of using } \\
\text { IUD }^{\star *}\end{array}$ & $13(28.3 \%)$ & $10(22.2 \%)$ & 0.712 \\
\hline Obesity $(>25 \mathrm{~kg} / \mathrm{m} 2)^{\star *}$ & $14(30.4 \%)$ & $11(24.4 \%)$ & 0.522 \\
\hline
\end{tabular}


When the mean pain severity of the groups was evaluated, no significant difference was observed between the groups. However, the mean VAS scores were higher in the Transverse application group $(p=0.347)$. When the presence of severe pain (VAS score $>8$ ) was evaluated, a statistically significant difference was observed between the groups $(\mathrm{p}=0.04)$. The presence of severe pain was significantly higher in patients with the transverse axis (Table 2).

Table 2. Pain scores of transverse and vertical application groups

\begin{tabular}{|lccc|}
\hline & $\begin{array}{c}\text { Transverse } \\
(\mathbf{n}=\mathbf{4 6})\end{array}$ & $\begin{array}{c}\text { Vertical } \\
(\mathbf{n}=\mathbf{4 5})\end{array}$ & $\mathbf{P}$ \\
\hline Pain score & $5.78 \pm 1.95$ & $5.44 \pm 1.41$ & 0.347 \\
Severe pain $(\text { VAS }>8)^{* *}$ & $13(28.3)$ & $5(11.1)$ & 0.040 \\
\hline $\begin{array}{l}{ }^{*} \text { Value was given as mean } \pm \text { SD. } \\
* \text { *Value was given as } \mathrm{n}(\%) .\end{array}$ & & & \\
\end{tabular}

Compared with patients with severe pain (VAS score $>8$ ) and patients without severe pain (VAS score $\leq 8$ ); No statistically significant difference was found in terms of BMI, cervical length, previous cesarean history, uterus being in a retrovert position, previously history of IUD usage and obesity. A statistically significant difference was observed in terms of age, gravida, parity, and in terms of application in the transverse plan $(\mathrm{p}<0.05)$. Patients with severe pain had lower patient age, gravida, and parity count; the frequency of IUD transverse application was higher (Table 3). Transverse application procedure (OR:1.21, 95\% CI:0.21-6.70, $\mathrm{p}=0.042$ ) as a result of multiple regression analysis of these significant factors were found to be significant independent factors (Table 4).

Table 4. Multiple regression analysis of factors that can cause severe pain

\begin{tabular}{|lcc|}
\hline & OR( \%95 CI) & p \\
\hline Age (year) & $0.97(0.81-1.16)$ & 0.721 \\
Gravida & $0.74(0.36-1.52)$ & 0.413 \\
Parity & $0.81(0.10-1.01)$ & 0.931 \\
Application on transverse axis & $1.21(0.21-6.70)$ & 0.042 \\
\hline
\end{tabular}

\section{DISCUSSION}

In our study, we investigated the possible effects of the axis of the wings while crossing the cervical canal to reach the cavity after the IUD wings are loaded into the cannula on pain perception during IUD insertion. According to the results, we obtained that the frequency of severe pain was higher in the transverse application group, though the pain scores between the two groups were similar. The transverse application was also the only independent factor associated with severe pain felt during the procedure.

Intrauterine device usage is beneficial for preventing unwanted pregnancies and reducing morbidity and mortality related to undesired pregnancies. It is preferred due to the same success rates as tubal sterilization; it is effective for a long time and is reversible (11).

One of the most significant limitations for IUD use is fear of pain prejudice during the procedure. Many studies were done about this issue; many pain medications have been tried in different ways (8-10). Local anesthetics that are applied topically or by injection can reduce cervical pain by blocking nerve fibers. Anxiolytics can also be used with the thought that it may decrease the perception of pain by reducing the patient's anxiety before insertion (12).

Some steps that could cause pain were identified during the insertion of IUD were defined as:: traction of the cervix, uterine traction to bring the cavity to a flat plane, the strain of the cervical canal by uterine sound or IUD cannula, and finally, possible traumas within the cavity (13). Our study aimed to reduce pain during the IUD insertion process without using a pharmacological method by evaluating the modifications regarding the cannula passage of the cervical canal, which is a part of the steps that may cause pain, with a randomized controlled study.

\section{Table 3. Comparison of demographic variables between groups with severe pain and without severe pain}

\begin{tabular}{|c|c|c|c|}
\hline & Severe pain $($ VAS $>8)(n=18)$ & Non-severe pain (VAS: $0-7)(n=73)$ & $\mathbf{P}$ \\
\hline Age $(\text { year })^{*}$ & $33.00 \pm 7.72$ & $37.58 \pm 4.53$ & $<0.001$ \\
\hline Gravida $^{*}$ & $1.94 \pm 0.55$ & $4.05 \pm 1.79$ & $<0.001$ \\
\hline Parity ${ }^{\star}$ & $1.44 \pm 0.35$ & $3.07 \pm 1.19$ & $<0.001$ \\
\hline BMI $(\mathrm{kg} / \mathrm{m} 2)^{*}$ & $25.91 \pm 4.33$ & $26.78 \pm 5.64$ & 0.542 \\
\hline Cervical length $(\mathrm{mm})^{*}$ & $39.83 \pm 5.86$ & $38.08 \pm 5.80$ & 0.255 \\
\hline CS presence ${ }^{\star \star}$ & $9(50.0)$ & $20(27.4)$ & 0.065 \\
\hline Retrovert uterus ${ }^{* *}$ & $3(16.7)$ & $22(30.1)$ & 0.252 \\
\hline The history of using IUD** & $3(16.7)$ & $20(27.4)$ & 0.419 \\
\hline Obesity $(>25 \mathrm{~kg} / \mathrm{m} 2)^{\star * \star}$ & $2(11.1)$ & $23(31.5)$ & 0.085 \\
\hline Pain score* & $8.11 \pm 0.47$ & $5.00 \pm 1.28$ & $<0.001$ \\
\hline Application on transverse axis ${ }^{* *}$ & $13(72.2)$ & $33(45.2)$ & 0.040 \\
\hline
\end{tabular}


The vast majority of the studies have been planned on drug versus placebo or a drug comparison. Abbas AM et al. (14) compared $150 \mathrm{mg}$ oral ketoprofen to a placebo. In the 10-point VAS assessment, the pain reduction in the ketoprofen group was around 1.5 points. In the same study, patient comfort and IUD insertion duration were also evaluated. Crawford et al. (15) compared oral ketorolac and the placebo group. There was a significant decrease in pain detected during the procedure and at the 10 th minute after the procedure $(\mathrm{p}=0.047, \mathrm{p}=0.007)$.

Another focus is on topical agents. The most commonly studied agent of these agents is lidocaine. Aksoy et al. (16) compared 10\% Lidocaine spray and placebo group, and pain scores were found to be $1.01 \pm 1.20,3.23 \pm 1.60$, respectively, when using a $10 \mathrm{~cm}$ scale $(\mathrm{V}<0.001)$.

Misoprostol is one of the most frequently used agent before birth, intervened abortion, or any procedure to be entered into the cavity, as it can provide cervical dilation (17).

Mansy et al. (18) studied $200 \mathrm{mg}$ misoprostol administered patients who had undergone IUD and the placebo group; no statistically significant difference was observed between the groups in terms of pain. Similar results were obtained in the study performed by İbrahim et al. (19) due to the side effects of misoprostol, and this drug is not recommended to be used before IUD insertion.

There are some studies that have aimed to reduce pain by using drugs during IUD administration; on the other hand, reducing pain with non-pharmacological methods has been more popular during recent years. Metoyer et al. (20), in their study, provided patients a comfortable position during the procedure and established turstbased communication. They reported that pain expected before the study was similar ( $\mathrm{p}=0.93)$, and pain after the study was less $(\mathrm{p}=0.17)$. Hylton et al. (21) compared the cold compress application and control group. It was determined as 4.5 and 4.7 in the evaluation with VAS $(p=0.724)$. It was not found significant statistically.

In our study, we found it more advantageous to apply the IUD on the vertical axis in terms of preventing severe pain felt during the procedure. The reason for this advantage may be due to neural control of the uterus. The nerve endings located on both sides of the cervical canal are closer and denser to the cervical canal $(22,23)$. It may be easier to stimulate these ends during the transverse passage. On the other hand, transverse administration may cause more uterine contraction, which may increase the frequency of severe pain.
As a result of our study designed as the first randomized controlled blind study in this area, we found that in the IUD application procedure, passing the cervical canal while the wings in cannula are in the vertical axis has been associated with less feeling of pain. IUD, which is frequently preferred as a safe, effective, and accessible contraceptive method. Further randomized and metaanalysis studies about reducing pain and increasing the patient's comfort during IUD placement would be obliging.

\section{ETHICAL DECLARATIONS}

Ethics Committee Approval: The study was carried out with the permission of University of Health Sciences Ankara Gulhane Medical Faculty Ethics Committee (Permission granted: 25/09/2018, Decision No: 18/229).

Informed Consent: Written informed consent was obtained from all participants who participated in this study.

Referee Evaluation Process: Externally peer-reviewed.

Conflict of Interest Statement: The authors have no conflicts of interest to declare.

Financial Disclosure: The authors declared that this study had received no financial support.

Author Contributions: All of the authors declare that they have all participated in the design, execution, and analysis of the paper and that they have approved the final version.

\section{REFERENCES}

1. Cleland J, Bernstein S, Ezeh A, Faundes A, Glasier A, Innis J. Family planning: the unfinished agenda. Lancet 2006; 368: 181027.

2. Cleland J, Conde-Agudelo A, Peterson H, Ross J, Tsui A. Contraception and health. Lancet 2012; 380: 149-56.

3. d'Arcangues C. Worldwide use of intrauterine devices for contraception. Contraception 2007; 75: 2-7.

4. Allen RH, Bartz D, Grimes DA, Hubacher D, O'Brien P. Interventions for pain with intrauterine device insertion. Cochrane Database Syst Rev 2009.

5. Kapp N, Curtis KM. Intrauterine device insertion during the postpartum period: a systematic review. Contraception 2009; 80: 327-36.

6. Cetin A, Cetin M. Effect of deep injections of local anesthetics and basal dilatation of cervix in management of pain during legal abortions: a randomized, controlled study. Contraception 1997; 56: $85-7$

7. Cooper N, Smith P, Khan K, Clark T. Vaginoscopic approach to outpatient hysteroscopy: a systematic review of the effect on pain. BJOG 2010; 117: 532-9.

8. Bednarek PH, Creinin MD, Reeves MF, et al. Prophylactic ibuprofen does not improve pain with IUD insertion: a randomized trial. Contraception 2015; 91: 193-7. 
9. McNicholas CP, Madden T, Zhao Q, Secura G, Allsworth JE, Peipert JF. Cervical lidocaine for IUD insertional pain: a randomized controlled trial. Am J Obstet Gynecol 2012; 207: 384.

10. Karabayirli S, Ayrım AA, Muslu B. Comparison of the analgesic effects of oral tramadol and naproxen sodium on pain relief during IUD insertion. J Minim Invasive Gynecol 2012; 19: 581-4.

11. Grimes DA, Hubacher D, Lopez LM, Schulz KF. Non-steroidal anti-inflammatory drugs for heavy bleeding or pain associated with intrauterine-device use. Cochrane Database Syst Rev 2006; 4: CD006034.

12. Murty J. Use and effectiveness of oral analgesia when fitting an intrauterine device. J Fam Plann Reprod Health Care 2003; 29: $150-1$.

13.Lopez LM, Bernholc A, Zeng Y, et al. Interventions for pain with intrauterine device insertion. Cochrane Database Syst Rev 2015.

14. Abbas AM, Ali SS, Salem MN, Sabry M. Effect of oral ketoprofen on pain perception during copper IUD insertion among parous women: a randomized double-blind controlled trial. Middle East Fertil Soc J 2018; 23: 491-5.

15. Crawford M, Davy S, Book N, Elliott JO, Arora A. Oral ketorolac for pain relief during intrauterine device insertion: a doubleblinded randomized controlled trial. J Obstet Gynaecol Can 2017; 39: 1143-9.

16. Aksoy H, Aksoy Ü, Ozyurt S, Açmaz G, Babayigit M. Lidocaine $10 \%$ spray to the cervix reduces pain during intrauterine device insertion: a double-blind randomised controlled trial. J Fam Plann Reprod Health Care 2016; 42: 83-7.

17. Garris RE, Kirkwood CF. Misoprostol: a prostaglandin E1 analogue. Clin Pharm 1989; 8: 627-44.

18. Mansy AA. Does sublingual misoprostol reduce pain and facilitate IUD insertion in women with no previous vaginal delivery? A randomized controlled trial. Middle East Fertil Soc J 2018; 23 72-6.

19. Ibrahim ZM, Sayed Ahmed WA. Sublingual misoprostol prior to insertion of a T380A intrauterine device in women with no previous vaginal delivery. Eur J Contracept Reprod Health Care 2013; 18: 300-8.

20.Stempinski-Metoyer K, Madrigal J, Adam M, Patel A. Utility of the comfort, assurance, language model (CALM) as a nonpharmacological intervention for pain relief during IUD insertion. Contraception 2018; 98: 354.

21. Hylton J, Milton S, Sima A. Cold compress for pain associated with intrauterine device insertion: a randomized controlled trial. Obs Gyn 2018; 131: 76.

22. Houdeau E, Rousseau A, Meusnier C, Prud'Homme MJ, Rousseau JP. Sympathetic innervation of the upper and lower regions of the uterus and cervix in the rat have different origins and routes. J Comp Neurol. 1998; 399: 403-12.

23. Aleksandrovych V, Kurnik-Łucka M, Bereza T, et al. The Autonomic Innervation and Uterine Telocyte Interplay in Leiomyoma Formation. Cell Transplant 2019; 28: 619-29. 